の順位を示すことが認められた。また，添加剤としてチ オ尿素を用いた場合は，これらの過電圧の差は減少する ことが認められた。

電着の結晶形については, 低電流密度 $\left(1 \mathrm{~mA} / \mathrm{cm}^{2}\right)$ では, (100) 面ではステップ和よびピラミッド型, (110) 面ではリッジ型，(111) 面では三角形，および六角形の 層状結晶を示した。高電流密度 $\left(10 \mathrm{~mA} / \mathrm{cm}^{2}\right)$ では, (100)牤よび (110) 面については，低電流密度の場合と 類似した形態を与えたが，(111）面では結晶形態が異な り，ほとんど無定形に近い結晶形を示し，電子回折像に より双晶の形成が認められた。

終りに，電子回折写真について有益なご助言を賜わっ た本学金属工学科 吉岡教授, 山本, 目良両氏に感謝す る。

(1965.10.19 受理)
文献

(1) J. O'M.Bockris, Transactions of the Symposium on Electrode Process, p. 161 (1959)

(2) R. Piontelli, G. Poli and G. Serravalle, Transactions of the Symposium on Electrode Process p. 67 (1959)

(3) S. C. Barnes, Electrochim, Acta, 5, 79 (1961)

(4) N. A. Economou, H. Fischer and D. Trivich, Electrochim. Acta, 2, 207 (1960)

（5）木下, 林, 石田, 本誌, 17, 184 (1966)

（6）山本美喜雄, 物理学講演集 (3) p. 193 (1943, 丸 善発行)

(7) J. Mindowicz, Electrochim. Acta, 6, 135(1962)

(8) G. Wranglén, Acta Chem. Scand., 9, 661(1955)

(9) N.A.Pangarov, Electrochim, Acta, 7, 139(1962)

(10) N.A.Pangarov, Electrochim. Acta, 9, 721(1964)

(11) 木下，林，石田，電化，34，42（1966）

(12) B. Ke, J.J. Hoekstra, B.C. Sison and D. Trivich, J. Electrochem. Soc., 106, 382 (1959)

\title{
尿素およびホウ酸を添加剂とする スルファミン酸浴による鉄電着
}

\section{林 禎一*・上野 浩* ・高木終司* \\ Electrodeposition of Iron from Sulfamate Baths Containing Urea and Boric Acid as Additives \\ Teiichi HAYASHI*, Hiroshi UENO* and Shushi TAKAGI*}

The effects of urea and boric acid were studied being added as brighteners to the bath composed of ferrous sulfamate and sulfamic acid. The additives were effective for buffers as well as brighteners.

It was examined on the effects of ferrous ion concentration, $\mathrm{pH}$, amounts of additives, temperature, and current density on current efficiency and surface imperfections. As the result, a bright deposit was obtained with no cracks or pits under the following conditions:

\begin{tabular}{|c|c|c|}
\hline Bath composition & ferrous ion & $28 \mathrm{~g} / l$ \\
\hline & urea & $180 "$ \\
\hline & boric acid & $25 "$ \\
\hline & $\mathrm{pH}$ & 2.2 \\
\hline & cature & $50^{\circ} \mathrm{C}$ \\
\hline & current density & $7 \sim 10 \mathrm{~A} / \mathrm{dm}^{2}$ \\
\hline
\end{tabular}

The Current density under the above conditions was ranged between 80 and $90 \%$.

Formation of ferric ion by oxidation caused many troubles such as decrease of current density, growth of surface imperfections, and poor adhesion. On the other hand, sulfate ion formed by hydrolysis of sulfamic acid had no harmful effects on the deposit even if its concentration was as high as $20 \mathrm{~g} / l$.

\section{1. ま えがき}

スルファミン酸浴によって鉄電着を初めて行なったの

†スルファミン酸浴による鉄電着（第1報）

* 工.業技術院名古屋工業技術試験所（要知紧名古屋市 北区平手町) Government Industrial Research Institute, Nagoya
は Piontelli ら ${ }^{122}$ ) で, 1939 年のことである。この浴は, スルファミン酸第 1 鉄とスルファミン酸を主成分とする ので，添加剤としてグリセリンを用いている。これから のち 約 20 年間の空白を経て, 1960 年に Barrett ${ }^{3)}$ が改 良浴を報告している。これは第 1 鉄が酸化されて第 2 鉄 になるのを防止するために，還元剤としてホルマリンあ 
るいはハイドロキノンを添加するすのである。をた浴に 緩衝作用を持たせるために，スルファミン酸フンモニウ ムも同時に添加している。この浴に続いて $\mathrm{Misra}^{4)}$ む, スルファミン酸アンモニウム添加浴を報告している。

鉄合金を，スルファミン酸浴によって電着することも 試みられている。鉄一コバルト，鉄一亜鉛などの合金に ついては Misra ${ }^{5) 6)}$ の報告があり, 緩衝剤として酢酸ナ トリウムを添加している。鉄一ニッケル合金について は，大野ら゙和よび戸田ら ${ }^{8)}$ の最近の報告がある。

合金電着は別として，上述の各浴を追試してみると， 電着面に巨視的なでこぼこを有していたり，粗面であっ たり，ヒビ割レやピットを有していたりといった状態 で, 実用に適するものがない。しかしスルファミン酸浴 の特色として, 電着物が靶性に富み, 内部応力が小さい こと，低い浴温を使用できることなどの利点が予想され る。したがって, これらの長所を生かして, 䉓着物の表 面状態を改善するような添加剤を追求する必要がある。

Machu ら9)は, 硫酸浴に尿素执よびホウ酸を添加する 方法を報告して扣り, 川崎ら ${ }^{10}$ は, その浴の特性と電着 物の物理的性質について検討している。筆者らる追試を 行ない，尿素は緩衝作用および浴の酸化防止に有効であ り,さらに光沢剤としても効果があること, ホウ酸は緩 衝作用は微弱であるが, 電着物に生じるヒビ割レを抑制 する作用があることを認めた。そこで尿素打よびホウ酸 をスルファミン酸浴に添加してみたところ，上述のよう な長所も認められ, かつ電流効率も高く, 光沢ニッケル メッキに近い光沢のある電着物を得ることができたの でそれらの結果を報告する。しかし $10 \mathrm{~A} / \mathrm{dm}^{2}$ 以上の 高電流密度に秃いて，ヒビ割レを生じる欠点を改善する ことはできなかった。

\section{2. スルファミン酸浴の基本的特性}

添加剤を加えないで, スルファミン酸第 1 鉄とスルフ アミン酸のみからなる浴について, 第 1 鉄の濃度, $\mathrm{pH}$, 浴温, および電流密度が電流効率括よび電着物の外観に 及ぼす影響を検討した。

\section{2-1 実験方法}

\section{2-1-1 浴の調製}

スルファミン酸第 1 鉄は市販されていないので, 次の よろにして浴を調製した。スルファミン酸 $500 \mathrm{~g} / l$ の溶 液に電解鉄粉を加え, 室温のままかきまぜて溶解させ た。溶解の進行とともに $\mathrm{pH}$ が上年し，3.0前後になっ たとさ口過して 鉄粉を除去する。液中の第 1 鉄を定量 し,これを原液とした。第 1 鉄の濃度が, $100 \sim 120 \mathrm{~g} / l$ の ものが得られた。この原液を分光分析にかけ，鉄以外の 金属イオンの存在を検したが, 検出されなかった。電着 浴を調製するときには，原液を所定の濃度にまで希釈
し,さらにスルファミン酸を加えて所定の $\mathrm{pH}$ に調節し た。電着浴は, すべて供試前に活性炭 $3 \mathrm{~g} / l$ を加兄, 活 性炭処理を行なった。

\section{2-1-2 実験装膡}

電解槽には $1 l$ 容量のビーカーを用い, $1 l$ の電着浴を 入れる。陽極には電解鉄を用い，浴に浸セキする部分の 寸法は $100 \mathrm{~mm} \times 30 \mathrm{~mm} \times 10 \mathrm{~mm}$ である。ビーカーの両 端の壁に接してこの陽極を 1 枚づつつるし，両陽極間の 中央に試験片を垂直につるして電着した。試験片は直径 $3.2 \mathrm{~mm}$ の銅棒で, 浴中に浸セキする長サは $100 \mathrm{~mm} て ゙$ ある。銅棒は油性研摩材により鏡面に仕上げ,加熱脱脂， 電解脱脂など慣行の脱脂処理を行なったのち, 試験に供 した。直流電源には蓄電池を使用した。浴は静止状態の まま電着し,カクハンは行なわなかった。電着厚サは 10 〜20 $\mu$ になるよ5にした。すなわち， $2 \mathrm{~A} / \mathrm{dm}^{2}$ 以下で電 着するときは電着時間は $30 \mathrm{~min}$ とし，3〜9 A/ $\mathrm{dm}^{2}$ で は $20 \mathrm{~min}, 10 \mathrm{~A} / \mathrm{dm}^{2}$ 以上では $10 \mathrm{~min}$ とした。

\section{2-2 実験結果および考寮}

\section{2-2-1 第 1 鉄濃度の影響}

浴温 $45^{\circ} \mathrm{C}, \mathrm{pH} 2.2$ の条件で $\mathrm{Fe}^{2+} 25 \sim 95 \mathrm{~g} / 1$ の範囲 内で, $\mathrm{Fe}^{2+}$ の濃度が電流効率に及ぼす影響を検討した。 結果を第 1 図に示す。 $\mathrm{Fe}^{2+}$ の濃度が增すとともに電流 効率は上年し， $95 \mathrm{~g} / l$ では $85 \%$ 以上飞達する。また高 濃度では, 低電流密度に和いて電流効率が低下寸る傾向 が少なくなる。電着物の表面状態を観察すると, 電流効 率の高いときには粗面となる傾向が強く，とくに $\mathrm{Fe}^{2+}$ $95 \mathrm{~g} / l$ の場合に著るしい。他方, 電流効率の低いときに はピットの発生が多くなる。

\section{2-2-2 pH の影響}

$\mathrm{pH} ! .8 \sim 2.2$ の範囲内で, $\mathrm{Fe}^{2+} 65 \mathrm{~g} / l$ と $\mathrm{Fe}^{2+} 95 \mathrm{~g} / \mathrm{l}$ の浴について, 浴温 $45^{\circ} \mathrm{C}$ に扔いて電流効率を測定した結 果を第 2 図に示す。 $\mathrm{pH}$ が高いときほど電流効率は高く なる。0.2 程度のわずかな $\mathrm{pH}$ の低下が, 著るしく電流 効率を低下させる。低 $\mathrm{pH}$ に打いては，電着物の平滑度 はよいが,ピットの発生が多い。ピットの発生は, $10 \mathrm{~A} /$

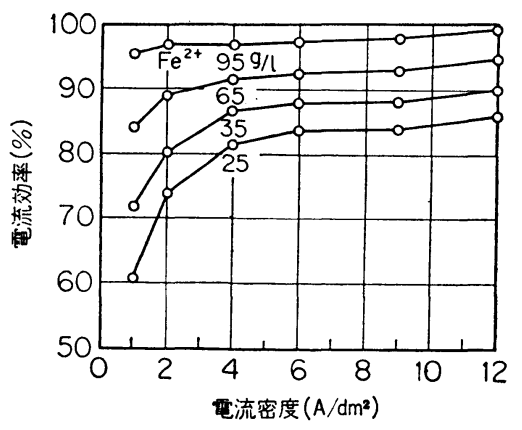

(浴温 $45^{\circ} \mathrm{C}, \mathrm{pH} 2.2$ )

第 1 図 第1 鉄の濃度と電流効率 
$\mathrm{dm}^{2}$ 以上の高電流密度に和いて著るし W。

\section{2-2-3 浴温の影響}

$30 \sim 80^{\circ} \mathrm{C}$ の範囲内で, $\mathrm{Fe}^{2+} 65 \mathrm{~g} / l$, pH 2.2 の浴について電流効率を測定し た。結果を第 3 図に示す。浴温が 30〜 $60^{\circ} \mathrm{C}$ の範囲内では, 電流効率に及ぼす浴 温の影響はきわめてわずかである。しか し $70^{\circ} \mathrm{C}$ 以上になると, 電流效率はかな り低下する。

\section{2--2-4 電流密度の影響}

第 1〜3図までで明らかなように, 電 流密度が低くなる汪ど電流効率は低下す る。この傾向は, 電流効率の低い浴ほど 顕著である。一般に, 電流密度対電流効 率の曲線の傾斜が大きいものは, 均一電

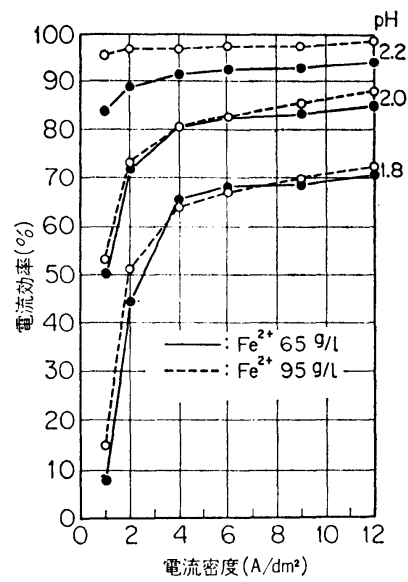

(浴温 $45^{\circ} \mathrm{C}$ )

第 2 図 $\mathrm{pH}$ と電流效率

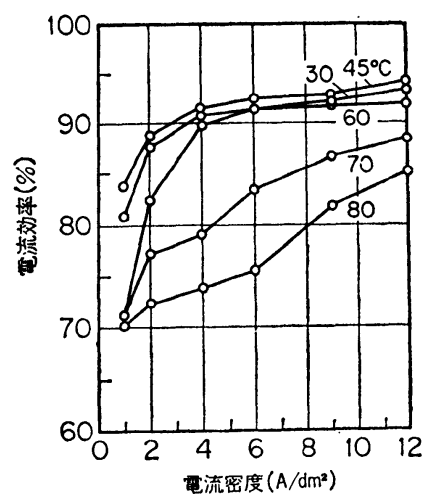

$\left(\mathrm{Fe}^{2+} 65 \mathrm{~g} / l, \mathrm{pH} 2.2\right)$

第 3 図浴温と電流效率
着性が低下するので，この点からしても電流効率の高い 浴が望ましいことになる。また，高電流密度でのピット の発生を考虑すると, 4〜 $10 \mathrm{~A} / \mathrm{dm}^{2}$ の電流密度が最適範 囲とみなされる。

\section{3. 添加剤の緩衛作用}

スルファミン酸第 1 鉄とスルファミン酸のみからなる 浴では, 緩衝作用が微弱であって, 電解中に $\mathrm{pH}$ が急速 に上升し，短時間の間に適正な $\mathrm{pH}$ の範囲を越える。 $\mathrm{pH}$ の上昇は第 1 鉄の酸化を促進し, 浴中に水酸化第 2 鉄が 生成して浴が濁る。尿素およびホウ酸が, この緩衝作用 にどのような効果を有しているか検討を加えた。

\section{3-1 実験方法}

$\mathrm{Fe}^{2+} 28.1 \mathrm{~g} / l$ 扎よび尿素とホウ酸 の所定量を含む溶液を調製し，スルフ アミン酸を加えて $\mathrm{pH}$ を1.7 にする。 この溶液 $100 \mathrm{cc}$ を採り, $0.5 N$ 水酸化

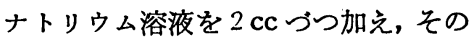
たびごとにガラス電極によって $\mathrm{pH}$ を

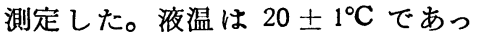
た。

\section{3-2 実赜結果およひ考察}

結果を第 4 図に示す。尿素の緩衝作 用は大きく, ホウ酸は比較的微弱であ る。両者の添加によって, $\mathrm{pH} 2.7$ 以 下で緩衝作用が大きくなる。スルファ ミン酸浴の好適 $\mathrm{pH}$ が, 前述のよ5 に 2.0 2.7 の範囲内にあることと考 え合せて, 両添加剂は緩衝作用の点か らも有効なるのと認められる。

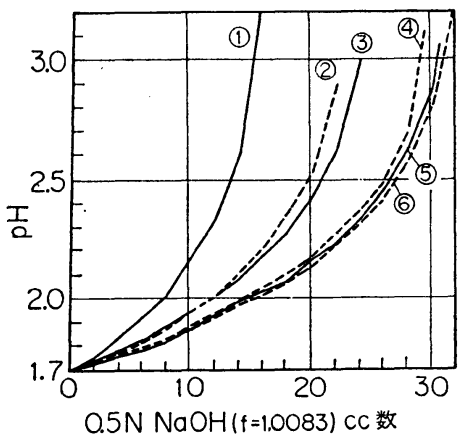

(1) 無添加液 $\left(\mathrm{Fe}^{2+} 28.1 \mathrm{~g} / l\right)$

(2) 尿素 $90 \mathrm{~g} / l$, 木ウ酸 $25 \mathrm{~g} / l$ 添加液

(3) 尿素 $135 \mathrm{~g} / /$, 小ウ酸 $25 \mathrm{~g} / l$ 添加夜

(4) 尿素 $180 \mathrm{~g} / l$ のみ添加液

(5) 尿素 $180 \mathrm{~g} / l$, ホウ酸 $25 \mathrm{~g} / l$ 添加夜

(6) 尿素 $180 \mathrm{~g} / l$, ホウ酸 $38 \mathrm{~g} / l$ 添加液

(試料 $100 \mathrm{cc}$, 液温 $20 \pm 1^{\circ} \mathrm{C}$ )

第4図尿素括よびホウ酸の緩衝作用

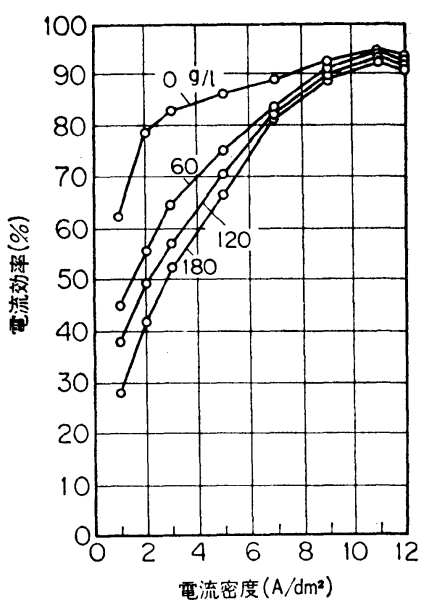

$\left(\mathrm{Fe}^{2+} 28.1 \mathrm{~g} / l\right.$, ホウ酸 $25 \mathrm{~g} / l, \mathrm{pH} 2.2$, 浴温 $50^{\circ} \mathrm{C}$ )

第 5 図 ホウ酸共存で尿素の添 加量と電流効率 


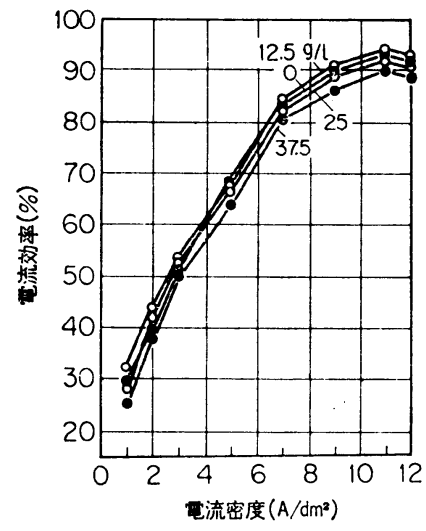

$\left(\mathrm{Fe}^{2+} 28.1 \mathrm{~g} / l\right.$, 尿素 $180 \mathrm{~g} / l, \mathrm{pH} 2.2$, 浴温 $50^{\circ} \mathrm{C}$ )

第 6 図 尿素共存でホウ酸の添加量 と.電流効率

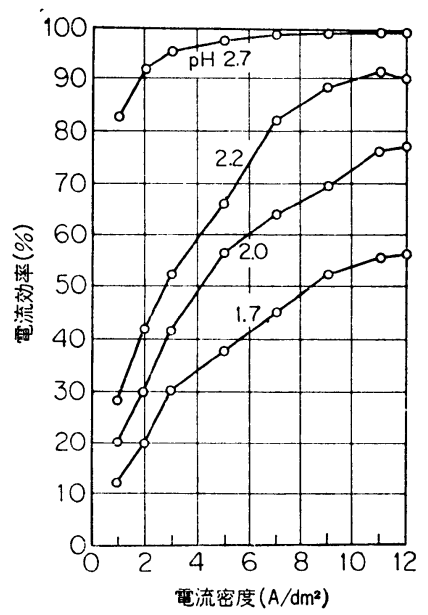

$\left(\mathrm{Fe}^{2+} 28.1 \mathrm{~g} / l\right.$, 尿素 $180 \mathrm{~g} / l$, ホウ酸 $25 \mathrm{~g} / l$, 浴温 $50^{\circ} \mathrm{C}$ )

第 7 図 尿素括よびホウ酸添加浴の $\mathrm{pH}$ と電流効率

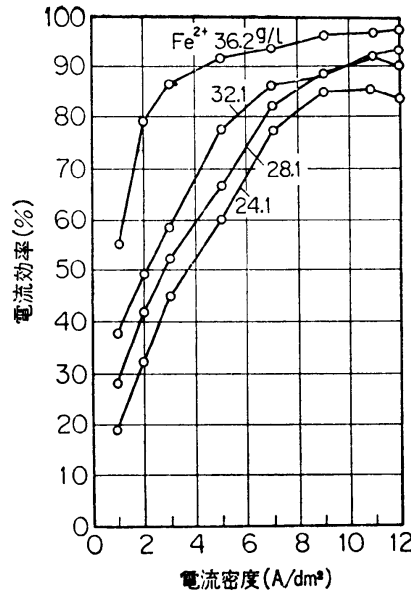

（㫱素 $180 \mathrm{~g} / l$, ホウ酸 $25 \mathrm{~g} / l, \mathrm{pH} 2.2$, 浴温 $50^{\circ} \mathrm{C}$ )

第 8 図尿素括よびホウ酸添加浴の 第 1 鉄の濃度と電流効率
$\mathrm{Fe}^{2+} 28.1 \mathrm{~g} / l$, ホウ酸 $25 \mathrm{~g} / l, \mathrm{pH} 2.2$ の浴に尿素を $0 \sim 180 \mathrm{~g} / l$ 添加したとき，尿素の添加量が電流効率に及

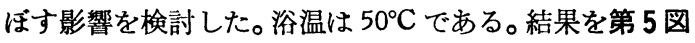
に示す。尿素の量が增加するに従って電流効率は減少 し, この傾向は, $7 \mathrm{~A} / \mathrm{dm}^{2}$ 以下の低電流密度に特いて特 に著るしい。電着物表面の平滑度は尿素の量が多いとき ほど良好であり， $180 \mathrm{~g} / l$ のときが最良であった。

\section{4-2-2 尿素共存でのホウ酸添加量の影響}

$\mathrm{Fe}^{2+} 28.1 \mathrm{~g} / l$, 尿素 $180 \mathrm{~g} / l, \mathrm{pH} 2.2$ の浴にホウ酸を $0 \sim 37.5 \mathrm{~g} / l$ 添加したとき，木ウ酸の添加量が電流効率 に及ぼす影響を検討した。䋧果を第 6 図に示す。ホウ酸 量が $37.5 \mathrm{~g} / l$ のときには, 無添加のときに比して電流 効率は $5 \%$ 弱低下する。しかし， $25 \mathrm{~g} / l$ 以下の添加では ほとんど影響がない。

電着物の表面状態を観察すると，ホウ酸を添加しない 浴ではヒビ割レが多数発生するが, 添加量の増加ととも に減少する。 $25 \mathrm{~g} / l$ 添加したとさは， $10 \mathrm{~A} / \mathrm{dm}^{2}$ 以上の 高電流密度の場合を除いて，ヒビ割レは認められない。 なお $37.5 \mathrm{~g} / l$ では粗面となる。したがって，ホウ酸の 添加量は電流効率および電着状態から見て, $25 \mathrm{~g} / l$ が適 量である。

\section{4-2-3 pH の影響}

$\mathrm{Fe}^{2+} 28.1 \mathrm{~g} / l$, 尿素 $180 \mathrm{~g} / l$, ホウ酸 $25 \mathrm{~g} / l$ の浴につ いて, $\mathrm{pH} 1.7 \sim 2.7$ の範囲内で $\mathrm{pH}$ が電流効率に及ぼす 影響を検討した。浴温は $50^{\circ} \mathrm{C}$ である。結果を第 7 図に 示す。 $\mathrm{pH}$ の低下に従い電流効率は急激に低下する。こ とに, $7 \mathrm{~A} / \mathrm{dm}^{2}$ 以下の低電流密度においてこの傾向が著 るしい。 $\mathrm{pH} 2.7$ では $95 \%$ 以上の高効率を示すが, 第 1 鉄の酸化が急速に進み, 水酸化第 2 鉄が䜿濁するよ 5 に
なる。 $\mathrm{pH} 2.2$ が最適である。このときの電着物の表面 状態も最良である。

\section{4-2-4 第 1 鉄の濃度の影響}

これまでの浴は $\mathrm{Fe}^{2+} 28.1 \mathrm{~g} / l$ を基準としたが,この 濃度の適否を確認する必要があり, 第 1 鉄の濃度の影響 を㭘討した。すなわち, ホウ酸 $25 \mathrm{~g} / l$, 尿素 $180 \mathrm{~g} / l$, $\mathrm{pH} 2.2$, 浴温 $50^{\circ} \mathrm{C}$ の条件は固定し, 第 1 鉄の濃度を $24.1 \mathrm{~g} / l$ から $36.2 \mathrm{~g} / l$ の間で变化させ, 電流効率を測定 した。結果を第 8 図に示す。添加剤のない場合の第 1 図 と比較すると，第 1 鉄の濃度の高いほど電流効率が高く なる傾向は同様であるが, 添加剤を加えた浴では第 1 鉄 の濃度がかなり低いにもかかわらず, 高い電流効率を示 す点で差異が認められる。また $7 \mathrm{~A} / \mathrm{dm}^{2}$ 以下の低電流 密度で, 電流密度対電流効率の曲線の傾斜が大きくなる 点も異なっている。

電着物の表面状態は, 第 1 鉄の濃度の増加にともない 粗面となる傾向が強くなる。またヒビ割レは, 濃度が減 少するほど多く発生するようになる。

これまでの実験結果を総合して, 次の浴を最適浴組成 として選んた。

$$
\left\{\begin{array}{lr}
\text { 第 } 1 \text { 鉄イオン } & 28 \mathrm{~g} / l \\
\text { 尿 素 } & 180 " \\
\text { ホウ酸 } & 25 " \\
\mathrm{pH} & 2.2
\end{array}\right.
$$

\section{4-2-5 浴温の影響}

上述の最適浴について, $30 \sim 60^{\circ} \mathrm{C}$ の範国内で検討し た。結果を第 9 図に示す。浴温が高くなるとともに, 電 流効率が上昇する傾向を示している。この傾向は, $7 \mathrm{~A} /$ $\mathrm{dm}^{2}$ 以上の高電流密度に拈いて著るしくなる。しかし, 


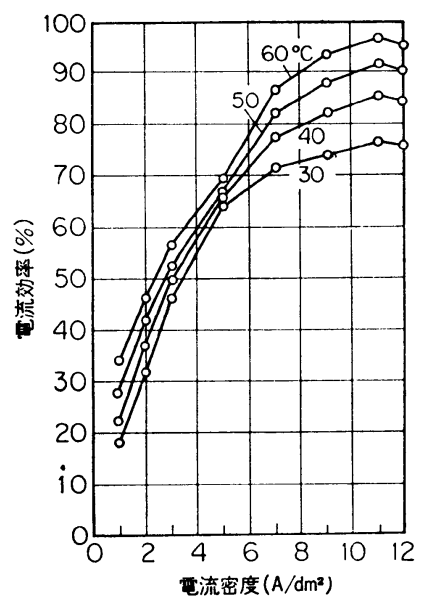

$\left(\mathrm{Fe}^{2}+28.1 \mathrm{~g} / l\right.$, 尿絭 $180 \mathrm{~g} / l$, ホウ酸 $25 \mathrm{~g} / l, \mathrm{pH} 2.2$ )

第 9 図尿素抢よびホウ酸添加浴の 浴温と電流効率

\section{4-2-6 電流密度の影響}

第 9 図について見ると，1〜9 A/dm² の範用内では， 電流密度の 増加とともに電流効率は増加する。しかし $9 \mathrm{~A} / \mathrm{dm}^{2}$ 以上の高電流密度では, 電流効摔はほとんど增 加せず一定值をとるようになる。他方, 電着物の表面状 態から見ると, $12 \mathrm{~A} / \mathrm{dm}^{2}$ ではヒビ割レやピットの発生 が認められる。以上の実験結果から, 電着条件は次のも のが最適である。

$$
\left\{\begin{array}{lc}
\text { 浴 温 } & 50^{\circ} \mathrm{C} \\
\text { 電流密度 } & 7 \sim 10 \mathrm{~A} / \mathrm{dm}^{2}
\end{array}\right.
$$

\section{5. 不純物の影湃}

ここで対象とする不純物とは，もともと浴成分として 加えられていたものが, 電解中に変化して浴中に蓄積し てくるもののみとする。この意味での不純物としては, 第 2 鉄イオンと硫酸イオンが考えられる。第 2 鉄は, 主 成分である第 1 鉄の酸化によって生成し, 硫酸イオンは スルファミン酸の加水分解によって生成する。

\section{5-1 第 2 鉄の影畡}

第 2 鉄は次のよ5にして調製した。前述の原液調製法 と同様にして, スルファミン酸酸性のスルファミン酸第 1 鉄溶液を調製する。この場合，第 1 鉄の濃度は $50 \mathrm{~g} / l$ 前後とし, 第 1 鉄を定量しておく。また $\mathrm{pH}$ は $1.0 〜 1.5$ にする。この溶液に過酸化水素水を加え, 第 1 鉄の大部 分を第 2 鉄に酸化する。残留している第 1 鉄を定量し, さきに定量した第 2 鉄との差から第 2 鉄の量を求める。 この溶液の所定量を電着浴に加えた。

第 2 鉄の量が電流効率に及ぼす影響を第 10 図に示す。 な敃第 10 図の電着浴の $\mathrm{pH} 1.7$ となって拈り, 前述
の最適 $\mathrm{pH} 2.2$ よ り低い,これは, pH 2.2 では第 2 鉄が沈殿し浴中に 緊濁する場命があ

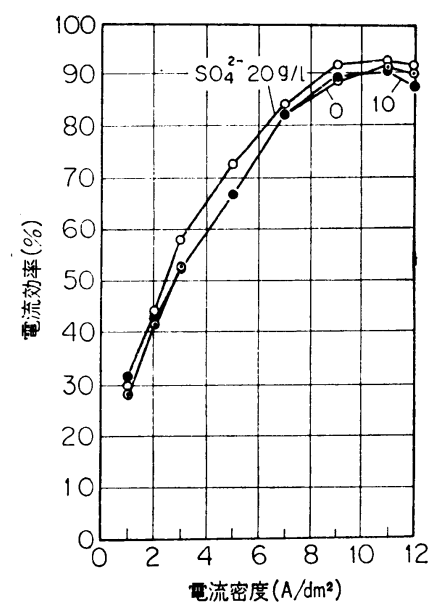

第 11 図硫酸イオンの量と 電流效率
り，それを避けるために低い $\mathrm{pH}$ を用いたのである。第 2 鉄は微量で電流効率を低下させる。たとえば $1.5 \mathrm{~g} / l$ で約 $10 \% ， 3 \mathrm{~g} / l$ では約 $15 \%$ 低下させている。第 2 鉄の 生成は，このように電流効率を低下させるばかりではな く, 電着表面の粗化拉よび密着不良を起こさせる。第 2 鉄を還元するには，金属鉄粉を浴に投入し溶解させる方 法が効果的である。

\section{5-2 硫酸イオンの影響}

硫酸イオンは, 硫酸ナトリウムとして添加した。硫酸 イオンの量が電流効率に及ぼす影響を第 11 図に示す。 硫酸イオンは, 電流効率にほとんど影響がない。しかし， $3 \mathrm{~A} / \mathrm{dm}^{2}$ 以下の低電流密度では電着表面が粗面となる。 この傾向は, 硫酸イオン $2.5 \mathrm{~g} / l$ の添加ですでに明瞭に 認められ, 添加量の増加にともないますます著るしくな る。前述のように, スルファミン酸浴の最適電流密度は $7 \sim 10 \mathrm{~A} / \mathrm{dm}^{2}$ であり, $3 \mathrm{~A} / \mathrm{dm}^{2}$ 以下の低電流密度での粗 面電着は実際的にはそれほど問題とならない。したがっ て硫酸イオンは, $20 \mathrm{~g} / l$ 存在しても無害と考えてよい。

\section{6. を め}

スルファミン酸第 1 鉄とスルファミン酸を主成分とす る鉄電着浴を改善する目的で, Machu らが硫酸浴にお いて光沢剤として好結果を得た沓素およびホウ酸を，ス ルファミン酸浴に添加することを試みた。その結果, 光 沢が光沢ニッケルメッキに匹敵し，ヒビ割レおよびピッ トのない電着物を次のような条件で得ることができた。

浴組成 $\left\{\begin{array}{lc}\text { 第 } 1 \text { 鉄イオン } & 28 \mathrm{~g} / l \\ \text { 尿 素 } & 180 \mathrm{~g} / l \\ \text { ホウ酸 } & 25 \mathrm{~g} / l \\ \mathrm{pH} & 2.2\end{array}\right.$


電着条件 $\left\{\begin{array}{lc}\text { 浴 温 } & 50^{\circ} \mathrm{C} \\ \text { 電流密度 } & 7 \sim 10 \mathrm{~A} / \mathrm{dm}^{2}\end{array}\right.$

上記の条件下での電流効率は, 電流密度によって变動 するが，括よそ 80 ないし $90 \%$ の籁囲内にあり，高電流 密度のときほど高い值を示す。

この浴の特性として，次のようなことがあげられる。

1）浴に緩衝作用があり， $\mathrm{pH}$ の上昇が緩慢である。

2）第 2 鉄へ酸化されにくい。

3）尿素の添加は電流効率を減少させるが, 光沢剤括 よび緩衝剤として效果が大きい。

4） $\mathrm{pH}$ の低下は電流効率を大きく減少させ， $\mathrm{pH}$ の 上䒜は電着物の表面を粗面とする。

5） $10 \mathrm{~A} / \mathrm{dm}^{2}$ 以上の高電流密度ではヒビ割レが生じ る。

6）第 2 鉄の生成は, 電流効率を低下させるばかりで なく, 電着物が粗面となるので $2 \mathrm{~g} / l$ 以下に保つ必 要がある。

7）スルファミン酸の加水分解により生成する硫酸イ オンは, $20 \mathrm{~g} / l$ に達しても無害である。

(1965. 12.6 受理)
(昭和 39 年 11 月 27 日九州工業大学に打ける 金属表面 技術協会第 30 回学術講演大会にて発表のものである。)

\section{文献}

(1) R.Piontelli and A.Guilotto, Chemica e Industria, 21, 478 (1939)

(2) R. Piontelli, Korr. Metallsch., 19, 110 (1943)

(3) R. C. Barrett, Proc. Am. Electroplaters' Soc., 47, 170 (1960)

(4) S. S. Misra, Indian J. Technol., 1, 208 (1963)

( 5 ) S. S. Misra and T. L. Rama Char, Plating, 51, 423 (1964)

(6) S.S.Misra and T.L.Rama Char, Metal Finishing, 62, No. 6, 88 (1964)

（7）大野 湶，戸田崇文，问 正夫，金表技，16，52 (1965)

（8）戸田崇文，大野 湶，向 正夫，金表技，16，241 (1965)

(9) W. Machu und M. F. M. El-Ghandour, Galvanotechnik, 51, 231 (1960)

（10）川崎元雄, 水本省三, 金表技, 13，464（1962）

\section{＜金属表面処理関連規格集（J IS）完成＞!!}

\section{価格 1 部 2,500 円}

\section{〔揭載内容例〕}

素材一覧, 電気メッキ用語, 電気メッキの記号による表示方法, 銀メッキ榆查方法, 電気亜鉛メッキ, カドミウム メッキ，鉄素地上のニッケル拈よびクロムメッキ，銅合金素地上のニッケル执よびクロムメッキ，覀鉛合金素地上 のクロムメッキ，工業用クロムメッキ，金メッキ，ニッケルメッキ拈よ゙ニッケル・クロムメッキ作業標準，メッ キ作業設備標準，工業用クロムメッキ作業標準，亜鉛合金素地上のクロムメッキ作業標準，溶融亜鉛メッキ，溶融 アルミニウム, 溶融亜鉛メッキ作業標準, 亜麻羽布, ラミ一羽布, 研摩材粒度, 研摩材・研削トイシ拈よび研摩布 紙の用語扣よび記号, 研摩布, 研摩紙, 耐水研摩紙, エンドレス研摩ベルト, 研摩ジスク, 金属前処理塗料, 航空 機機体特よび機体部品の金属表面処理, 航空機機体部品の塗料ならびに防護被覆, エリクセン試験方法, ビッカー スカタサ試験方法, 曲ゲ試験方法, 塩水噴霧試験方法, サビ発生度測定方法, 塗料一般試験方法, 自動車部品の塗 膜通則，ウェザーメーター(塩水噴霧試験を含む)，自動車部品のメッキ通則，キャス試験方法（コロードコート試 験方法を含む), 溶融亜鉛メッキ試験方法, スズメッキ試験方法, 覀鉛溶射製品試験方法, 鉛溶射製品試験方法, アルミニウム溶射製品試験方法, 溶融アルミニウムメッキ試験方法, 金属表面のポリエチレン皮膜試験方法, 2 度 視野に打ける色のX, Y, Z 系による表示方法, 三属性による色の表示方法, 物体色の測定方法, 表面色の此較方 法, 色名, 色に関する用語, キセノン標準白色光源, 光沢度测定方法。

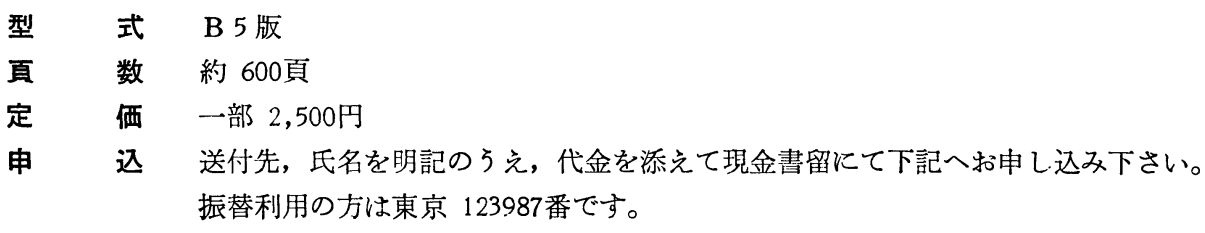

東京都千代田区神田岩本町 2 共同ビル 社団法人 金 属 表 面 技 術協 会 